\title{
A Study to Assess the Level of Anxiety among Tuberculosis Patients Admitted in Government Hospital, Sasaram, Rohtas-District Bihar
}

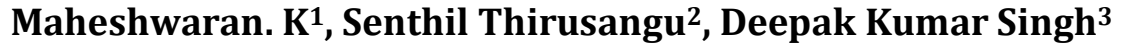 \\ 1Psychiatric Nurse, ${ }^{2}$ Assistant Professor, ${ }^{3}$ Nursing Tutor \\ ${ }^{1}$ District Mental Health Programme Unit, Government Hospital, Sasaram, Rohtas, Bihar, India \\ ${ }^{2}$ Rama Nursing College (Rama University) , Kanpur, Uttar Pradesh, India \\ ${ }^{3} \mathrm{Gnm}$ Institute Anugrah Narayayan Magadh Medical Collegee, Gaya, Bihar, India
}

\begin{abstract}
How to cite this paper: Maheshwaran. K | Senthil Thirusangu | Deepak Kumar Singh "A Study to Assess the Level of Anxiety among Tuberculosis Patients Admitted in Government Hospital, Sasaram, Rohtas-District Bihar" Published in International Journal of Trend in Scientific Research and Development (ijtsrd), ISSN: 24566470, Volume-3 | Issue-3, April 2019, pp.175-178, URL: http://www.ijtsrd.co $\mathrm{m} /$ papers/ijtsrd217 00.pdf

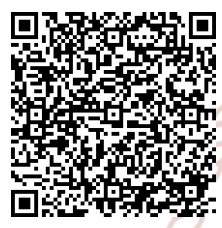
IITSRD21700
\end{abstract}

Copyright (C) 2019 by author(s) and International Journal of Trend in Scientific Research and Development Journal. This is an Open Access article distributed under the terms of the Creative Commons Attribution License (CC BY 4.0) (http://creativecommons.org/licenses/ by/4.0)

\section{INTRODUCTION}

The World Health Organization, defined health as a state of complete physical, mental, and social well-being and not a merely absence of disease or infirmity. The impact of any disease, especially a chronic illness like tuberculosis, on an individual patient is therefore often all-encompassing, affecting not only his physical health but also his psychological, economic, and social well-being. Although these results provide important information regarding the disease, it is often impossible to separate the disease from the individual's personal and social context, especially in chronic and progressive diseases.

Tuberculosis is one of the leading causes of mortality and morbidity around the world, infecting approximately 8 billion people, with an annual death rate of close to 1 million. India shares almost a third of this global tuberculosis burden. With nearly 2 million incidents cases and half a million deaths annually, tuberculosis is certainly an enormous public health problem in this country.

\section{STATEMENT OF THE PROBLEM:-}

A study to Assess the Level of Anxiety Among Tuberculosis Patients Admitted in Government Hospital, Sasaram, RohtasDistrict Bihar

\section{OBJECTIVE OF THE STUDY:-}

Assess the level of anxiety in clients with tuberculosis and associate the level of anxiety with socio-demographic variables

\section{RESEARCH METHODOLOGY:}

RESEARCH APPROACH:- Non experimental cross sectional survey method was used for the present study.

\section{RESEARCH DESIGN:-}

Simple descriptive design, which is one of the non Experimental designing, was used for the present study.

\section{SETTING OF THE STUDY:-}

The study was conducted in Tuberculosis unit of Government Hospital, Sasaram, Rohtas-District Bihar 


\section{POPULATION:-}

The population for this study consists of all patients with tuberculosis of both male and female admitted in Chest and TB. Government Hospital, Sasaram, Rohtas-District Bihar.

\section{SAMPLE:-}

The sample of the present study consist of patients with tuberculosis admitted in Tuberculosis \& chest unit in Government Hospital, Sasaram, Rohtas-District Bihar during the time of data collection

\section{SAMPLE SIZE:-}

A sample size is 30 patients who are diagnosed with pulmonary tuberculosis and admitted in inpatient department of tuberculosis unit for medical care.

\section{SAMPLING TECHNIQUE:-}

Purposive sampling technique will be used for the present study.

\section{RESEARCH VARIABLES:-}

Level of Anxiety among tuberculosis is the research variable in this study.

\section{DEMOGRAPHIC VARIABLE:-}

Some common demographic variables are age, gender, marital status, religion, educational status, occupation, type of family, area of residence, family history of tuberculosis,

\section{SAMPLING CRITERIA:-}

Inclusion Criteria:- Patients who are diagnosed as suffering from tuberculosis and admitted in chest and TB. Unit, Government Hospital, Sasaram, Rohtas-District, Bihar. Patients who can read, write, speak and understand Hindi language .Patients who are willing to participate in the study. Exclusion criteria:- Patients who cannot follow the instructions. Patients who are not available during the period of data collection.

The tool consists of two sections.

SECTION-A: - It consists of demographic data such as age, gender, occupation, residence area, religion, type of family.

SECTION-B: - It consists of five point rating scale to assess the level of anxiety among the tuberculosis patient admitted in Government Hospital, Sasaram, Rohtas-District, Bihar.

Totally it consists of 15 items. The maximum score is $75 \&$ minimum score is 15 .

Score 1-25 indicates mild anxiety. Score 26-50 indicates moderate anxiety. Score 51-75 indicates severe anxiety.

\begin{tabular}{|c|c|}
\hline LEVEL OF ANXIETY & SCORING \\
\hline Mild anxiety & $1-25$ \\
\hline Moderate anxiety & $26-50$ \\
\hline Severe anxiety & $51-75$ \\
\hline
\end{tabular}

\section{VALIDITY OF TOOL:-}

Content validity was done in consultation with the research committee of the college.

\section{METHODS OF DATA COLLECTON:-}

Demographic data were collected using a structured base line perform prepared by investigator. Anxiety levels of tuberculosis patient were assessed by the five point rating scale.

\section{DATACOLLECTION PROCEDURE:-}

The data collection was schedule from 18 to 30 in the month of April 2016. Before the data collection the investigator obtained the formal permission from the Chief Medical Superintendent to conduct the study. Before the data collection the investigator obtained the formal permission from the Chief medical superintendent to conduct the study in Government Hospital, Sasaram, Rohtas-District, Bihar. Consent from patient is obtained to conduct the study.

\section{ANALYSIS AND INTERPRETATION:-}

Organization and presentation of data:- The data analysis was done by the descriptive and inferential statistics. The analysis was done based on the objectives. The demographic data would we analyzed in terms of descriptive statistics. The data analysis was as follows. Organize data in master sheet or computer. Personal data would be analyzed in terms of frequencies an percentage. Relationship between the variable and association was analyzed on the inferential statistics.

\section{SECTION - A:-}

TABLE 1:- Distribution of tuberculosis patients according to their demographic variables.

\begin{tabular}{|c|c|c|c|}
\hline $\begin{array}{l}\text { S. } \\
\text { No }\end{array}$ & $\begin{array}{l}\text { Demografic } \\
\text { Variable }\end{array}$ & Frequancy & Percentage \\
\hline 1. & AGE IN YEAR & & \\
\hline A & $10-15$ Year & & \\
\hline B & 16-20 Year & & \\
\hline $\mathrm{C}$ & 21-25 Year & 10 & 33.3 \\
\hline D & 26-More & 20 & 66.7 \\
\hline 2. & IUITC GENDAR & & \\
\hline $\mathrm{A}$ & Male & 18 & 60 \\
\hline $\mathrm{B}$ & Female & 12 & 40 \\
\hline 3. & MARITAL STATUS & & \\
\hline A & Married & 26 & 86.7 \\
\hline $\mathrm{B}$ & Unmarried & 4 & 13.3 \\
\hline $\mathrm{C}$ & Separated & & \\
\hline D & Widows / Widower & & \\
\hline 4. & RELIGION & & \\
\hline A & Hindu & 28 & 93.3 \\
\hline $\mathrm{B}$ & Muslims & 2 & 6.7 \\
\hline $\mathrm{C}$ & Christian & & \\
\hline $\mathrm{D}$ & Other & & \\
\hline 5. & OCCUPATION & & \\
\hline A & Private job & 15 & 50 \\
\hline $\mathrm{B}$ & Government job & & \\
\hline $\mathrm{C}$ & Coolie \& Agriculture & & \\
\hline $\mathrm{D}$ & Unemployed & 15 & 50 \\
\hline 6. & $\begin{array}{l}\text { EDUCATIONAL } \\
\text { STATUS }\end{array}$ & & \\
\hline A & Primary education & 21 & 70 \\
\hline $\mathrm{B}$ & Intermediate & 9 & 30 \\
\hline $\mathrm{C}$ & Graduate & & \\
\hline 7. & TYPE OF FAMILY & & \\
\hline $\mathrm{A}$ & Small family & 14 & 46.7 \\
\hline $\mathrm{B}$ & Extended family & 16 & 53.3 \\
\hline 8. & AREA OF RESIDENC & & \\
\hline A & Rural & 24 & 80 \\
\hline $\mathrm{B}$ & Urban & 6 & 20 \\
\hline $\mathrm{C}$ & Slums & & \\
\hline 9. & FAMILY HISTORY & & \\
\hline A & Maternal side & 2 & 6.7 \\
\hline
\end{tabular}


International Journal of Trend in Scientific Research and Development (IJTSRD) @ www.ijtsrd.com eISSN: 2456-6470

\begin{tabular}{|c|c|c|c|}
\hline B & Paternal side & 8 & 26.7 \\
\hline C & Other & 20 & 66.6 \\
\hline
\end{tabular}

\section{SECTION-B:-}

This section deals with the association between the demographic variables and anxiety level score of subjects to assess the level of anxiety among tuberculosis patients.

Fisher exact $\mathrm{Z}$ test was used to find out association between the level of anxiety \& demographic variables such as age in year, gender, marital status, religion, occupation, educational status, type of family, area of residence, family history.

\begin{tabular}{|c|c|c|c|}
\hline $\begin{array}{c}\text { S. } \\
\text { No }\end{array}$ & Demografic Variable & $\mathrm{Z}$ & Inference \\
\hline 1. & AGE IN YEAR & & \\
\hline $\mathrm{A}$ & $10-15$ Year & \multirow{4}{*}{4.86} & \multirow{4}{*}{$\begin{array}{c}\text { Significant } \\
\mathrm{P}<4.86 \text { at } \\
0.05 \text { level }\end{array}$} \\
\hline $\mathrm{B}$ & $16-20$ Year & & \\
\hline $\mathrm{C}$ & $21-25$ Year & & \\
\hline $\mathrm{D}$ & 26-More & & \\
\hline 2. & GENDER & & \\
\hline $\mathrm{A}$ & Male & \multirow[b]{2}{*}{6.67} & \multirow{2}{*}{$\begin{array}{c}\text { significant } \\
\mathrm{P}<6.67 \text { at } 0.05 \\
\text { level }\end{array}$} \\
\hline B & Female & & \\
\hline 3. & MARITAL STATUS & & \\
\hline $\mathrm{A}$ & Married & \multirow{4}{*}{3.36} & \multirow{4}{*}{$\begin{array}{l}\text { significant } \\
\mathrm{P}<3.36 \text { at } \\
0.05 \text { level }\end{array}$} \\
\hline $\mathrm{B}$ & Unmarried & & \\
\hline $\mathrm{C}$ & Separated & & \\
\hline $\mathrm{D}$ & Widows & & \\
\hline 4. & RELIGION & \multirow{5}{*}{3.44} & \multirow{5}{*}{$\begin{array}{l}\text { significant } \\
\mathrm{P}<3.44 \text { at } 0.05 \\
\text { level }\end{array}$} \\
\hline $\mathrm{A}$ & Hindu & & \\
\hline $\mathrm{B}$ & Muslims & & \\
\hline $\mathrm{C}$ & Christian & & \\
\hline $\mathrm{D}$ & Other & & \\
\hline 5. & OCCUPATION & O & Co \\
\hline $\mathrm{A}$ & Privet job & \multirow{4}{*}{0.78} & \multirow{4}{*}{$\begin{array}{c}\text { Not significant } \\
\mathrm{P}>0.78 \text { at } \\
0.05 \text { level }\end{array}$} \\
\hline $\mathrm{B}$ & Government job & & \\
\hline $\mathrm{C}$ & Coolie \& Agriculture & & \\
\hline $\mathrm{D}$ & Unemployed & & \\
\hline 6. & EDUCATIONAL STATUS & & Qn \\
\hline $\mathrm{A}$ & Primary education & \multirow{3}{*}{11.11} & \multirow{3}{*}{$\begin{array}{c}\text { significant } \\
P<11.11 \text { at } \\
0.05 \text { level } \\
\end{array}$} \\
\hline $\mathrm{B}$ & Intermediate & & \\
\hline $\mathrm{C}$ & Graduate & & \\
\hline 7. & TYPE OF FAMILY & & \\
\hline $\mathrm{A}$ & Small family & \multirow[b]{2}{*}{1.08} & \multirow{2}{*}{$\begin{array}{c}\text { Not significant } \\
P>1.08 \text { at } \\
0.05 \text { level }\end{array}$} \\
\hline $\mathrm{B}$ & Extended family & & \\
\hline 8. & AREA OF RESIDENC & & \\
\hline $\mathrm{A}$ & Rural & \multirow{3}{*}{15} & \multirow{3}{*}{$\begin{array}{c}\text { significant } \\
\mathrm{P}<15 \text { at } 0.05 \\
\text { level } \\
\end{array}$} \\
\hline $\mathrm{B}$ & Urban & & \\
\hline $\mathrm{C}$ & Slums & & \\
\hline 9. & FAMILY HISTORY & & \\
\hline $\mathrm{A}$ & Maternal side & \multirow{3}{*}{0.26} & \multirow{3}{*}{$\begin{array}{c}\text { Not significant } \\
P>0.26 \mathrm{at} \\
0.05 \text { level }\end{array}$} \\
\hline $\mathrm{B}$ & Paternal side & & \\
\hline $\mathrm{C}$ & Other & & \\
\hline
\end{tabular}

$\mathrm{Z}=$ Fisher exact $\mathrm{z}$ test.

Table 2: Shows that there is significant association among the demographic variables \& level of anxiety as like Age in year, Gender, Marital status, Religion, Educational status and

area of residence with the Level of Anxiety at 0.05 level of significant.

\section{Major finding of the study:-}

\section{Demographic Variables:}

Majority of Tuberculosis patients according to their age reveals that $66.7 \%$ were in the age group of 26 years or more and $33.3 \%$ were in the age group of 21-25 year. Majority of Tuberculosis patients according to their sex reveals that $60 \%$ were male and $40 \%$ were female. Majority of Tuberculosis patients according to their marital status reveals that $86.7 \%$ were married and $13.3 \%$ were unmarried. Majority of Tuberculosis patients according to their religion reveals that $93.3 \%$ were Hindu and $6.7 \%$ were Muslims. Majority of Tuberculosis patients according to their occupational status reveals that $50 \%$ were doing private job and $50 \%$ were unemployed. Majority of Tuberculosis patients according to their educational status reveals that $70 \%$ were educated up to primary level and $30 \%$ completed intermediate. Majority of Tuberculosis patients according to their types of family reveals that $53.3 \%$ were from extended family and $46.7 \%$ were from small family. Majority of Tuberculosis patients according to their area of residence reveals that $80 \%$ were from rural area and $20 \%$ were from urban area. Majority of Tuberculosis patients according to their family history of tuberculosis reveals that were $26.7 \%$ has paternal side \& $6.7 \%$ has maternal side and $66.6 \%$ others. A study was conducted to assess the level of anxiety among tuberculosis patients. The main aim of the study was to determine level of anxiety among tuberculosis patients. Across sectional study was performed in a sample of 70 tuberculosis patients, the result of the study revealed that $66.7 \%$ of our sample presented significant level of anxiety. So our study found severe level of anxiety among tuberculosis patients.

\section{Distribution of sample according to their level of anxiety:}

Majority of tuberculosis patients has moderate level of anxiety $66.7 \%$ and severe level of anxiety $33.3 \%$.

\section{To association the sample of demographic variable with level of anxiety:}

Out of 30 samples, there is significant association among the demographic variables like age, gender, marital status, religion, education status and area of residence with level of anxiety. Occupational status, type of family, family history was not associated with level of anxiety. There was high significant association between Age, gender, marital status, religion, educational status and area of residence with level of anxiety. There was high significant associated between age and level of anxiety as the calculated value is higher than the able value at 0.05 interval which is 4.86 . There was high significant association between gender and level of anxiety as the calculate value is higher than table value at 0.05 which is 6.67.There was high significant associated between marital status and level of anxiety as the calculate value is higher than the able value at 0.05 interval which is 3.36.There was high significant associated between religion and level of anxiety as the calculate value is higher than the able value at 0.05 interval which is 3.44 .There was high significant associated between education status and level of anxiety as the calculate value is higher than the able value at 0.05 interval which is 11.11.There was high significant associated between area of residence and level of anxiety as the calculate value is higher than the able value at 0.05 interval which is 15 . 


\section{CONCLUSION:-}

Anxiety is a serious mental illness that is characterized by distress, fear which can lead to increase risk of clinical of depression. Majority of tuberculosis patients $(66.7 \%)$ has moderate level of anxiety and (33.3\%) severe level of anxiety .There is association between the demographic variables likes area of residence \& educational status with level of anxiety. Anxiety become a serious health threat that for tuberculosis patient by predisposing them to and increase risk of clinical depression. There is need of awareness among tuberculosis patients in rural area and urban area. This study suggested that medical professionals had focused on promoting knowledge by giving health education regarding prevention of anxiety among the tuberculosis patients.

\section{References:}

[1] Bowling A. Measuring diseases a review of diseases specific quality of life measurement scale, Milton Keynes's open university press 2995.

[2] Abhinay goyal salin yosuf "The impact of post hospital home care on patient with pulmonary tuberculosis "Indian journal research, September 2006, 54(s) page no. 235- 224.
[3] Brenes GA, anxiety and chronic obstructive pulmonary disease, prevalence impact, and treatment psychometric medicine 2003: 65, 963, 970.

[4] Kumari Neelam, A text book of community health

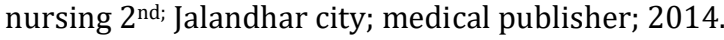

[5] Chaulet P. Problems of tuberculosis in the world today sohweiz Med Mochenschr, 1983 Jan 22.113 (2):71-4.

[6] Park k, Text book of preventive and social medicine, $18^{\text {th }}$ edition, Jabalpur, Banorsidas Bhanot publisher , 2005 , page no. 160

[7] PSI healthy lives measurable result; PSI tuberculosis programme bull; India, 2011.

[8] Kerlinger, Nursing Research. $1^{\text {st }}$ edition. Published by Reed Elsevier, New Delhi Pvt. Ltd. 2008, 123

[9] Polit D. E and Beck C.T. Nursing Research Generating and Assessing evidence for nursing Practice 2009, New Delhi, Walters Pvt. Ltd. $8^{\text {th }}$ edition V.G. published by Elsevier Indian Private limited 2008.

[10] Sharma S. K, Nursing Research and Statistics. 2 $2^{\text {nd }}$ edition. Published by Elsevier, a division Of Reed Elsevier India Private Limited. 2012

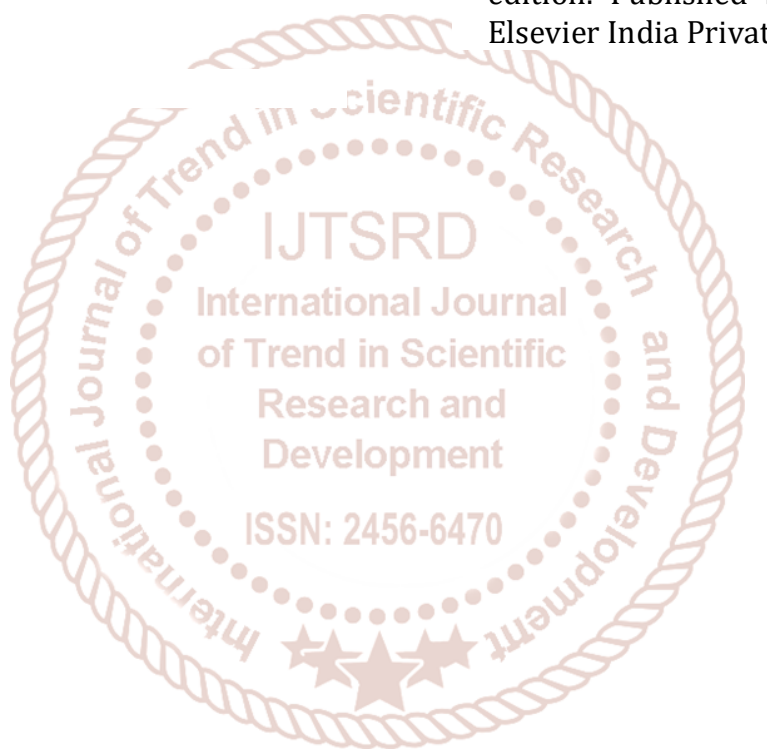

